\title{
Enhancing Performance of Silty Clayey Sandy and of Pavement Using Cement and Geogrid in South Republic of Benin (West Africa)
}

\author{
Alaye Quirin Engelbert Ayeditan ${ }^{1,2, *}$, Agbadogbe Senan Jeannot ${ }^{3}$, Toure Youssouf ${ }^{4}$, \\ Chango Valere Loic ${ }^{2}$, Assogba Ogoubi Cyriaque ${ }^{2}$ \\ ${ }^{1}$ Department of Civil Engineering, University of Abomey-Calavi, Cotonou, Benin \\ ${ }^{2}$ Department of Civil Engineering, Harbin Institute of Technology, Harbin, China \\ ${ }^{3}$ Department of Civil Engineering, The Associated Engineering Partnership, Cotonou, Benin \\ ${ }^{4}$ Department of Civil Engineering, Northeast Forestry University, Harbin, China

\section{Email address:} \\ alaye47@yahoo.fr (A. Q. E. Ayeditan),jagbadogbe@yahoo.fr (A. S. Jeannot), tianlaiyu@126.com (T. Youssouf), \\ chanshola@gmail.com (C. V. Loic), assocyr@gmail.com (A. O. Cyriaque) \\ ${ }^{*}$ Corresponding author
}

\section{To cite this article:}

Alaye Quirin Engelbert Ayeditan, Agbadogbe Senan Jeannot, Toure Youssouf, Chango Valere Loic, Assogba Ogoubi Cyriaque. Enhancing Performance of Silty Clayey Sandy and of Pavement Using Cement and Geogrid in South Republic of Benin (West Africa). International Journal of Mineral Processing and Extractive Metallurgy. Special Issue: Enhancing Performance of Soil and Precluding Landslide in Africa. Vol. 5, No. 3, 2020, pp. 42-53. doi: 10.11648/j.ijmpem.20200503.12

Received: September 15, 2020; Accepted: October 15, 2020; Published: October 26, 2020

\begin{abstract}
Pavement infrastructure built on expansive soil can experience multiple forms of degradation, mainly cracks when there are no adequate arrangements made to avoid or to limit the impact of the changes on the volume of the supporting soil. In this research, three objectives have been adopted in-depth on the performance characteristics of West Africans soil and aim to (i) accessing characteristics of soil types in the region; (ii) assessing the performance of these soils with $2 \%, 2.5 \%, 3 \%, 3.5 \%$, $4 \%, 4.5 \%, 5 \%$ and $5.5 \%$ of cement and (iii) using geogrid to evaluate the performance of pavement on clayey soil. Design of flexible pavement is largely based on empirical methods using layered elastic and two-dimensional finite element (FE) analysis Currently a shift underway towards more mechanistic design techniques to minimize the limitations in determining stress, strain and displacement in pavement analysis. For this reason, computational analysis of pavement methods have been investigated on the structural model pavement and the effectiveness of geogrids as a reinforcement of layer in a flexible pavement system. In this study, flexible pavement modeling is done using Abaqus software in which model dimensions, element types and meshing strategies are taken by successive trial and error to achieve desired accuracy and convergence of the research. Flexible pavements (with and without geogrids) were built and subjected to $127.49 \mathrm{kN}$ load applications and the Finite Element Method (FEM) as computer analysis under static load. The results reveal that the proportion of percentage cement leading to the best performances varying from $3 \%$ to $5.5 \%$. And, the pavement made with geogrid in subgrade is the best. As a conclusion, in an unstable area, this research suggests the use of silty clayey sandy treated with a minimum percentage of 3\% cement in subbase layer and geogrid in subgrade because, the inclusion of geogrid in subgrade reduces the deformation.
\end{abstract}

Keywords: Soil, Flexible Pavements, Cement, Geogrid, Finite Element Method

\section{Introduction}

To categorize the soil, the new approach has been adopted: using geological mapping to identify the soil's characteristics by performing laboratory analysis [1-4]. The infrastructure builds on expansive soils present enormous disorders, especially when no special provisions were made during their development. The particularities of expansive soils have long been known that there are multiple works and publications 
dedicated to expansive soils [5-13]. The geotechnical properties of the soil that can be used to determine the suitability of the soil to support engineering structures with regard to the soil's stability to be assessed [14].

With the increased advancement in personal computer technology, during the last decades, finite element methods (FEM) offer the potential for thorough and comprehensive analyses of flexible pavement systems at an affordable cost. Others researchers used the ABAQUS finite element program to explore the decrease in the rut depth of reinforced flexible paved sections. In particular, three locations of geosynthetic reinforcement were studied: at the base-subgrade interface, and inside the base layer at the height of $1 / 3$ of its thickness from the bottom [15].

In addition, a lot of previous research have referred to bidimensional (2D) numerical analysis rather than three dimensional (3D). The reason is due because this last requires considerably more computational time and powerful and expensive computers. However, the necessity of adopting the $3 \mathrm{D}$ analysis arises from the following advantages [16]: i) it better reflects the complex behavior of the composite pavement system materials under different configurations traffic loads; ii) it is preferred when verifying numerical model results with laboratory or field test results; iii) it allows the simulation of the loaded wheel footprint.

In this research, after the enhancement of the performance of silty clayey sand by cement, the evaluation of the performance of pavement using geogrid was done in order to examine which performed better. Furthermore, this research aimed at investigating the performance of flexible pavement reinforced by geogrid under traffic load using numerical analysis.

\section{Studied Area}

The topographic profile of the studied area, illustrated in Figure 1, points out that the encircled study area is located in the lowest altitudes of the profile. This section of road passes through a geographical basin with an average altitude of $60 \mathrm{~m}$ above the level of the sea. The studied area contains a lot of water during the rainy seasons. The latter is at its minimum in August, the maximum first peak in June, and the second peak in October. The annual rainfall heights vary between 551 and $1871 \mathrm{~mm}$ and are distributed on average between 90 to 110 days. Average temperatures range is between 29 to $38^{\circ} \mathrm{C}$.

Concerning the stratigraphy, a graphical representation of the stratigraphy shows the depths at which the clayey soil layer lies at various kilometer points of the project. Stratigraphy was performed manually with the auger.

Figure 2 shows the depths at which the clayey soil layer lies at different kilometric points of the study. During the earthworks; the clayey soil was not removed at certain kilometric points.

For over a decade, the sub-sector is confronted with a scarcity of materials of good quality to implement in the realization of projects of constructions and or reinforcements.

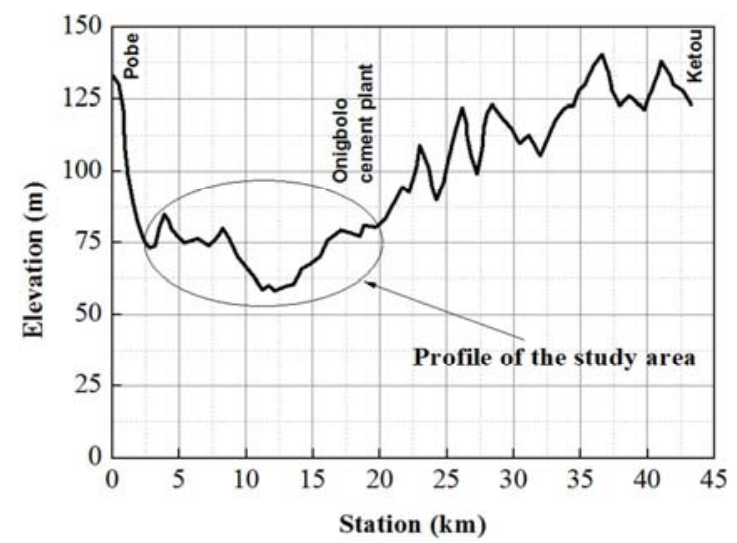

Figure 1. Topographic profile of the studied area.

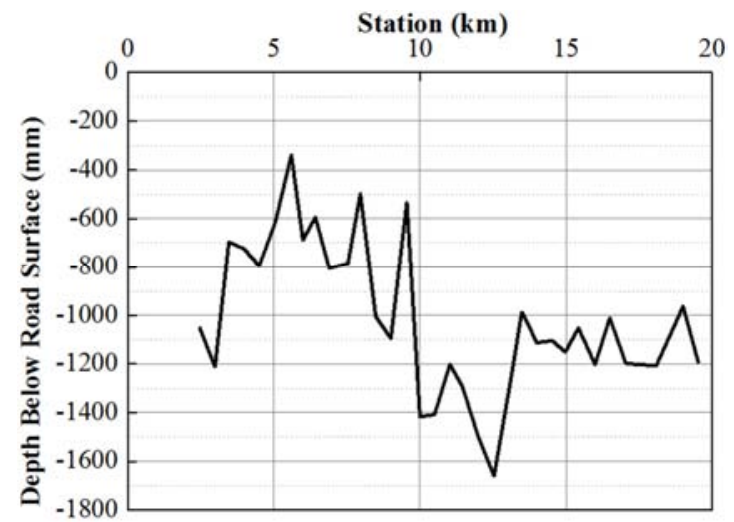

Figure 2. Depth of the expansive clayey layer in relation to the existing road.

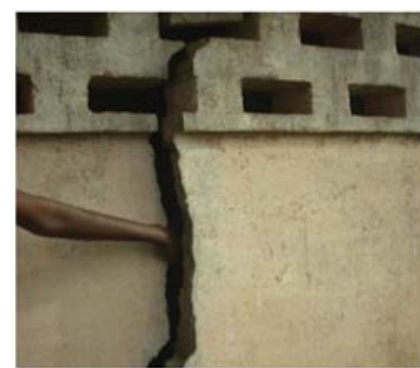

a. Gaping cracks in the wall of a classroom

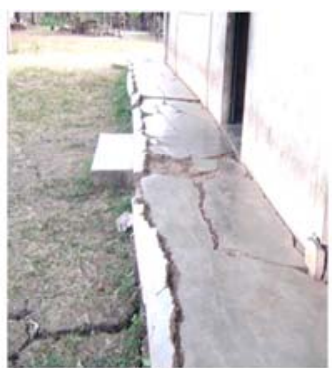

b. Disorders in the form of exterior building

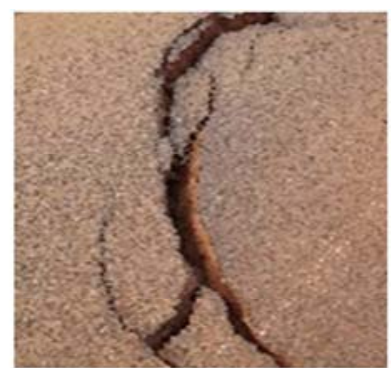

c. Wide cracks on pavement

Figure 3. Cracks in infrastructures founded on clayey soil in southern Benin. 

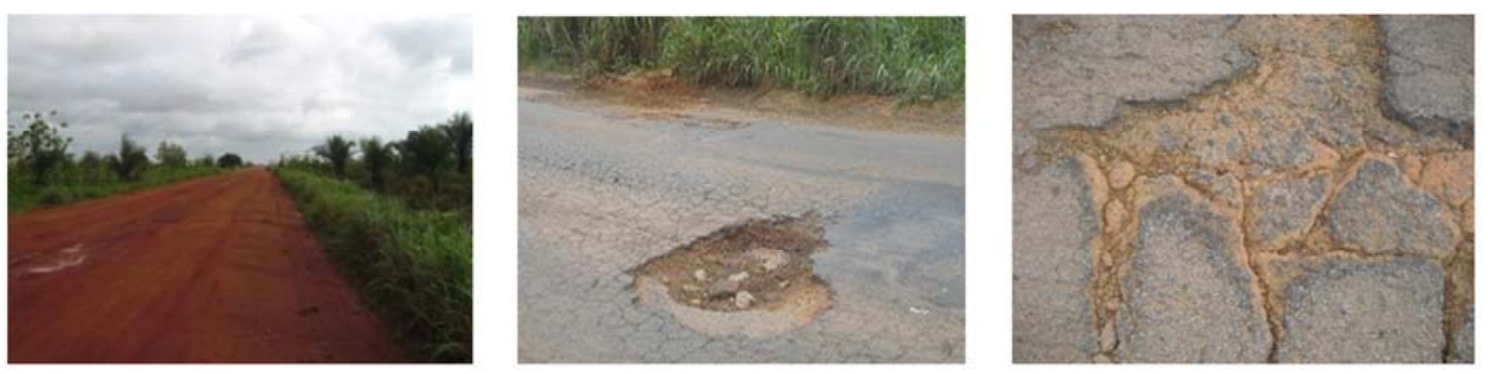

Figure 4. Degradation observed on pavements in the region of the Lama.
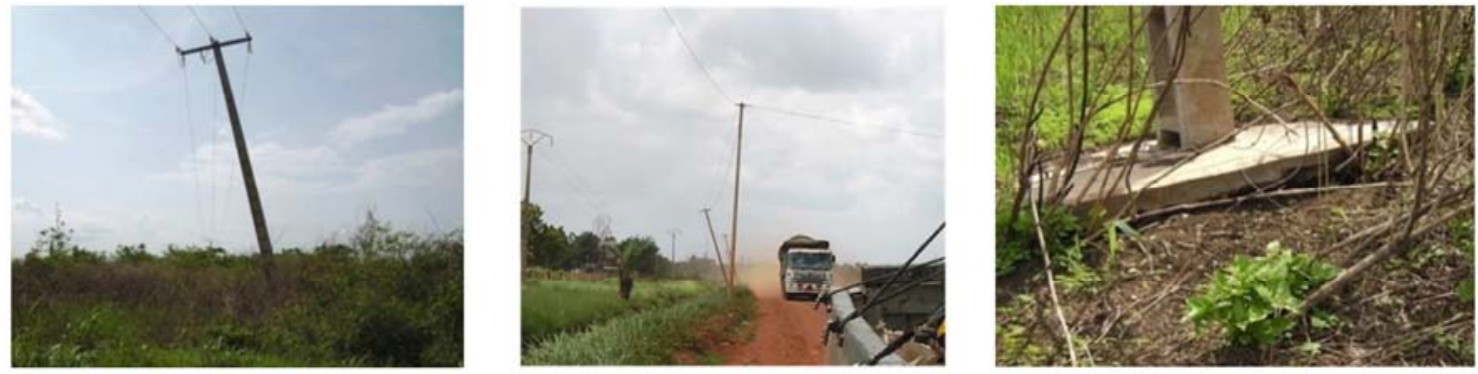

Figure 5. Tilt of electric poles and detachment of their sole in the region of Lama.

of the pavements. In southern regions in particular, these materials are becoming increasingly scarce in the areas of road projects to be carried out, making them expensive because of distance of transport which are abnormally exaggerated, and due to the remoteness of quarries which can be exploited. The major concern should be due to economic constraints, to achieve the use of locally available materials.

The southern Benin is rich in clayey sandy but with low geotechnical performance. Their use in layers of roadway requires an improvement beforehand. The illustrations in Figures 3-5 demonstrate the disorders caused by these soils on the infrastructure (peeling, sagging and fracturing due to shrinking and swelling of the ground are remarked on).

In addition, the road Calavi-Bohicon-Dan is a point of passage for the major part of the local traffic connecting the south and the north of the country and for all the users of the countries of the hinterland such as Niger, Burkina Faso and Mali. This results in heavy traffic is important, generating a sudden, considerable stress of the pavement structure. This stretch of the main road as well as other in the country (section Pobe - Onigbolo and stretch Come-Lokossa to the right of the village of Kpinou) have the particularity to cross the depression of the Lama, the area where there are instabilities due to swelling soils. The mobilization of a budget constantly increasing their maintenance almost ineffective today prompted us to reflect on the topic: "Structural model performance and reinforced pavement technology in south Republic of Benin (West Africa)," which has the aim to propose a methodological approach leading to concrete solutions specific.

\section{Materials and Methods}

\subsection{Comparison of the Geotechnical Point of View}

The geotechnical tests were carried out from kilometric point $15+750$ to $16+200$. In this section, the samples were taken from three wells $(1 \mathrm{~B}, 2 \mathrm{~B}, 3 \mathrm{~B})$. These tests were carried out on the basis of the following tests: sieve particle test and sedimento metry test according to norms $[17,18]$ in order to have the clay content percentage; the Atterberg limits test was in accordance to the norms [19]. Modified Proctor test was according to standard [20]; and classification was according to [21].

\subsection{Improvement Silty Clayey Sandy with Cement}

According to French standards NF P94-093 [20] eight (8) dosages were retained for the curing of cement materials, for instance, $2 \%, 2.5 \%, 3 \%, 3.5 \%, 4 \%, 4.5 \%, 5 \%$ and $5.5 \%$. Apart from the classical identification tests, the Proctor test and California bearing ratio (CBR) tests were done by following Belgian standards EN13286-2 [22] and EN1328650 [23] respectively. The compression and tension tests were done on an improved sample, namely compression strength and tension strength at $7 \mathrm{~d}$ air bath, then compression strength at $3 \mathrm{~d}$ air bath and $4 \mathrm{~d}$ water bath and tension strength at $21 \mathrm{~d}$ air $7 \mathrm{~d}$ bath, finally compression and tension at $28 \mathrm{~d}$ in air. This approach was helped for the improvements from the curing of silty clayey sandy by the addition of cement which will favor the rational use of this improved soil in a pavement layer.

\subsection{Numerical Modeling of Pavement Method}

\subsubsection{Material Characterization}

Assuming three layers of pavement: crushed stones base, lateritic gravelly treated with cement subbase and subgrade. All pavement materials were assumed to respond linearly and elastically to the applied load as static load was applied in the linear perturbation step. Elastic properties (modulus of elasticity and Poisson's ratio) were obtained from previous investigation [24]. Some random material properties were 
also given to understand the pavement response under different condition.

Table 1 shows the experimental material properties from experimental tests, used in the finite element analyses.
Membrane elements were used to mesh the geogrid. The samples of soil from section $15+750$ to $15+850$ and $16+100$ to $16+200$ are subgrade 1 and 2 , respectively.

Table 1. Experimental Material Properties used in the FEM.

\begin{tabular}{lllll}
\hline Layers & Elastic Modulus (MPa) & Poison's Ratio & Temperature $\left({ }^{\circ} \mathbf{C}\right)$ & Thick-ness (cm) \\
\hline surfacing & 2700 & 0.3 & 30 & 15 \\
Crushed-stone base & 1600 & 0.3 & No & 20 \\
Improved cement subbase & 650 & 0.3 & No & 20 \\
Geogrid & 44 & 0.25 & No & 0.22 \\
Subgrade 1 & 60 & 0.3 & No & 275 \\
Subgrade 2 & 70 & 0.3 & No & 275 \\
\hline
\end{tabular}

\subsubsection{Model Geometry}

In this study, dynamics loading areas are idealized by rectangular areas. A rectangular loading plate of dimension $0.25 \mathrm{~mm} \times 0.25 \mathrm{~mm}$ was used to apply the wheel load on the pavement section.

In relation to memory space and analysis runtime, a quarter cube model has the advantage over the others because of its two axes of symmetry. Overall dimensions (i.e., length, width, and depth) of this model are $4 \times 4 \times 3 \mathrm{~m}$. The number of layers, as well as thicknesses of every layer, is assigned by the earlier description of the structural model pavement section.

\subsubsection{Load Distribution}

The elastic-viscoelastic correspondence principle was applied directly to moving loads as indicated by Huang in the multilayer system [25]. The complexities of the analysis and a large amount of computer time make these methods unsuited for practical use. Therefore, a simplified method has been used in both Vesy and Kenlayer.

In this method, it is assumed that the intensity of the load varies with time according to a haversine function. The load function used is expressed as Equation (1).

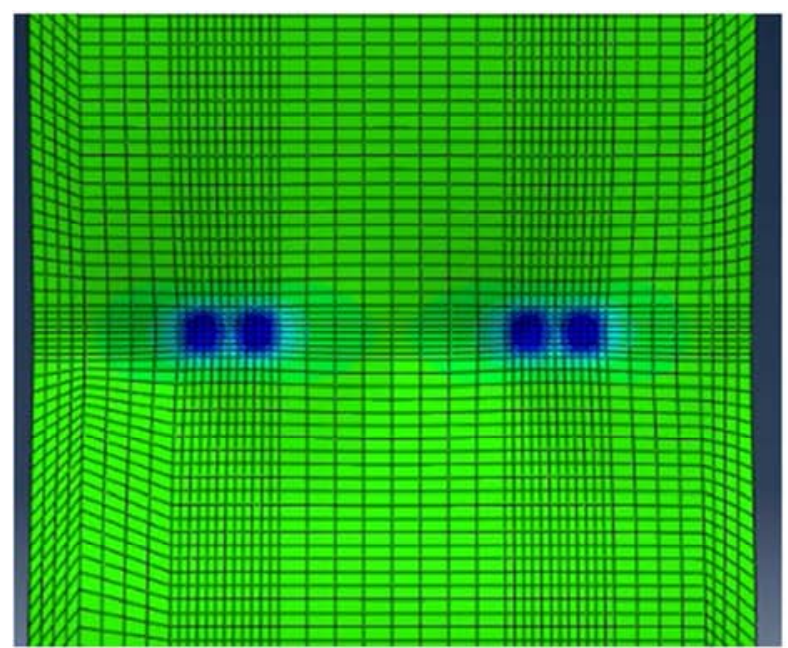

$$
L(t)=q \sin ^{2}\left(\frac{\pi}{2}+\frac{\pi t}{d}\right)
$$

Where $\mathrm{d}$ is the duration of the load. When the load is at a considerable distance from a given point, or $t= \pm \frac{d}{2}$ the load above the point is zero, or $\mathrm{L}(\mathrm{t})=0$. When the load is directly above the given point, or $\mathrm{t}=0$, the load intensity is $\mathrm{q}$.

The duration of load depends on the vehicle speed (S) and the tire contact radius (a). A reasonable assumption is that the load has practically no effect when it is at a distance of $6 \mathrm{a}$ from the point, or Equation (2)

$$
d=\frac{12 a}{s}
$$

Where $\mathrm{s}=20 \mathrm{~km} / \mathrm{h}$ and $\mathrm{a}=0.14 \mathrm{~mm}$

Figure 6 shows finite element mesh for laboratory pavement section under static load.

\subsubsection{Boundary and Contact Modeling}

Displacement constraints were used to simulate the body (base layer, subbase layer) and the subgrade's support of pavement structure. These elements, which act as springs to the ground, provide a simple way of including the stiffness effects of the subgrade without of nodes at the bottom of the model.

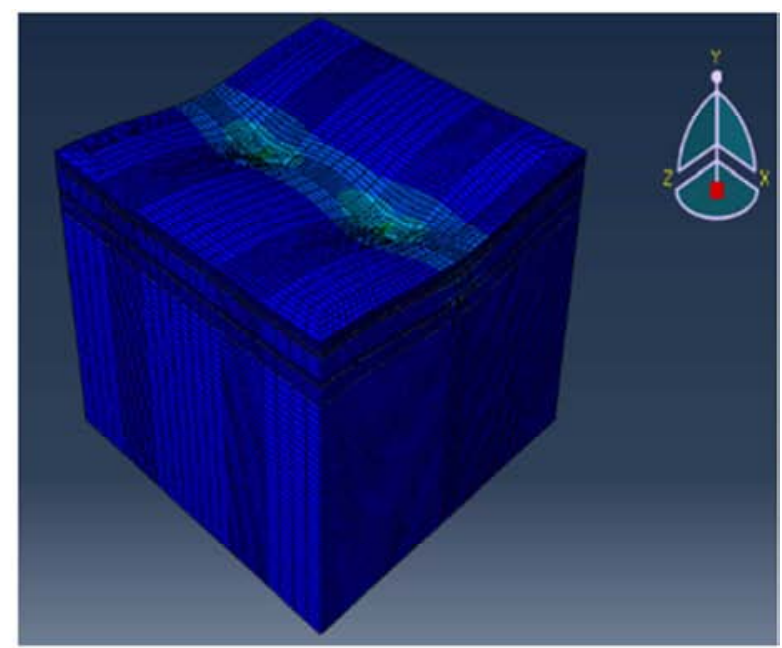

Figure 6. Finite element mesh for laboratory pavement section under static load.

Interaction properties between two adjacent layers were assumed as perfectly bonded so frictionless contact was given. In some cases, frictional properties were assigned at the interface between the loading plate and the base layer. 


\section{Results and Discussions}

\subsection{Experimental Results}

\subsubsection{Sieve Tests}

The results of sieve tests are shown in Tables 2, 3 and 4.

These results of particle size test (Tables 2, 3 and 4) show that in this section of the pavement, the very fine soil with a percentage of fines $(<80 \mu \mathrm{m})$ very high going over $89.6 \%$ for Well 1B, 55.6\% for Well 2B and $86.6 \%$ for Well 3B. Also, the studied soil consists of nearly $60 \%$ grains smaller than 20 $\mu \mathrm{m}$.

\subsubsection{Atterberg Limit Test}

The results are shown in Tables 5,6 and 7. According to the results from Atterberg limit test (Tables 5, 6 and 7), it appears that for these three wells, the plasticity index is superior to 40 . Therefore, the materials of the tree wells are very plastic.

\subsubsection{Organic Matter Content}

The results are shown in Table 8 . The values of the organic matter content (OMC) obtained indicate at well 1B are superior to $2 \%$ and less than $3 \%(2 \%<\mathrm{OMC}<3 \%)$; While the values of the organic matter content of wells $2 \mathrm{~B}$ and $3 \mathrm{~B}$ are less than $2 \%(\mathrm{OMC}<2 \%)$. Additionally, the results of the organic matter content of wells 1B (Table 8), show that the soil is poorly organic $(2 \%<\mathrm{OMC}<3 \%)$; the materials of wells $2 \mathrm{~B}$ and $3 \mathrm{~B}$ are very poorly organic $(\mathrm{OMC}<2 \%)$.

Table 2. Results of Particle Size Analysis of Well 1B.

\begin{tabular}{|c|c|c|c|c|c|c|c|c|c|c|}
\hline \multicolumn{4}{|l|}{ Sieve } & \multicolumn{7}{|c|}{ Sedimentometry } \\
\hline Opening & Retained & & Passing & Time & Temperature & $\begin{array}{l}\text { Read } \\
\text { value }\end{array}$ & Correction & $\begin{array}{l}\text { Read } \\
\text { value }\end{array}$ & Diameter & Percentage \\
\hline Size & Aggregate Mass & Cumulative & & 30" & $27^{\circ} \mathrm{C}$ & 9.5 & 2.5 & 12 & 0.08 & 89.6 \\
\hline $\mathbf{m m}$ & Retained/g & weight/g & $\%$ & 1' & $27^{\circ} \mathrm{C}$ & 9 & 2.5 & 11.5 & 0.055 & 85.9 \\
\hline 8 & 0 & 0 & 100 & 2 ' & $27^{\circ} \mathrm{C}$ & 7.5 & 2.5 & 10 & 0.038 & 74.7 \\
\hline 5 & 0 & 0 & 100 & 5 & $27^{\circ} \mathrm{C}$ & 7 & 2.5 & 9.5 & 0.025 & 70.9 \\
\hline 2 & 5 & 1 & 99 & 10 & $27^{\circ} \mathrm{C}$ & 6.5 & 2.5 & 9 & 0.017 & 67.2 \\
\hline 1.25 & 8 & 1.6 & 98.4 & $20^{\prime}$ & $27^{\circ} \mathrm{C}$ & 5.5 & 2.5 & 8 & 0.012 & 59.7 \\
\hline 0.4 & 20 & 4 & 96 & $40^{\prime}$ & $27^{\circ} \mathrm{C}$ & 5 & 2.5 & 7.5 & 0.009 & 56 \\
\hline 0.32 & 22 & 4.4 & 95.6 & $1 \mathrm{~h} 20^{\prime}$ & $27^{\circ} \mathrm{C}$ & 4 & 2.5 & 6.5 & 0.006 & 48.5 \\
\hline 0.15 & 34 & 6.8 & 93.2 & $2 \mathrm{~h} 00$ & $27^{\circ} \mathrm{C}$ & 2.5 & 2.5 & 5 & 0.005 & 37.3 \\
\hline 0.08 & 52 & 10.4 & 89.6 & $24 \mathrm{~h} 00^{\prime}$ & $27^{\circ} \mathrm{C}$ & 1 & 2.5 & 3.5 & 0.0014 & 26.1 \\
\hline
\end{tabular}

Table 3. Results of Particle Size Analysis of Well 2B.

\begin{tabular}{|c|c|c|c|c|c|c|c|c|c|c|}
\hline \multicolumn{4}{|l|}{ Sieve } & \multicolumn{7}{|c|}{ Sedimentometry } \\
\hline Opening & Retained & & Passing & Time & Temperature & $\begin{array}{l}\text { Read } \\
\text { value }\end{array}$ & Correction & $\begin{array}{l}\text { Read } \\
\text { value }\end{array}$ & Diameter & Percentage \\
\hline Size & Aggregate Mass & Cumulative & 0 & 30" & $27^{\circ} \mathrm{C}$ & 10.5 & 2.5 & 13 & 0.08 & 55.6 \\
\hline $\mathbf{m m}$ & Retained/g & weight/g & $\%$ & 1 ' & $27^{\circ} \mathrm{C}$ & 10 & 2.5 & 12.5 & 0.055 & 54.4 \\
\hline 8 & 0 & 0 & 100 & 2 & $27^{\circ} \mathrm{C}$ & 8.5 & 2.5 & 11 & 0.038 & 47.9 \\
\hline 5 & 31 & 6.2 & 93.8 & 5 , & $27^{\circ} \mathrm{C}$ & 8 & 2.5 & 10.5 & 0.025 & 45.7 \\
\hline 2 & 54 & 10.8 & 90.2 & 10 & $27^{\circ} \mathrm{C}$ & 7 & 2.5 & 9.5 & 0.017 & 41.4 \\
\hline 1.25 & 112 & 22.4 & 77.6 & $20^{\prime}$ & $27^{\circ} \mathrm{C}$ & 6.5 & 2.5 & 9 & 0.012 & 39.2 \\
\hline 0.4 & 123 & 24.6 & 75.4 & 40 ' & $27^{\circ} \mathrm{C}$ & 6 & 2.5 & 8.5 & 0.009 & 37.0 \\
\hline 0.32 & 164 & 32.8 & 67.2 & $1 \mathrm{~h} 20^{\prime}$ & $27^{\circ} \mathrm{C}$ & 5 & 2.5 & 7.5 & 0.006 & 32.7 \\
\hline 0.15 & 189 & 37.8 & 62.2 & $2 \mathrm{~h} 00^{\prime}$ & $27^{\circ} \mathrm{C}$ & 3.5 & 2.5 & 6 & 0.005 & 26.1 \\
\hline 0.08 & 217 & 43.4 & 55.6 & $24 \mathrm{~h} 00^{\prime}$ & $27^{\circ} \mathrm{C}$ & 2 & 2.5 & 4.5 & 0.001 & 19.6 \\
\hline
\end{tabular}

Table 4. Results of Particle Size Analysis of Well 3B.

\begin{tabular}{|c|c|c|c|c|c|c|c|c|c|c|}
\hline \multicolumn{4}{|l|}{ Sieve } & \multicolumn{7}{|c|}{ Sedimentometry } \\
\hline Opening & Retained & & Passing & Time & Temperature & $\begin{array}{l}\text { Read } \\
\text { value }\end{array}$ & Correction & $\begin{array}{l}\text { Read } \\
\text { value }\end{array}$ & Diameter & Percentage \\
\hline Size & Aggregate Mass & cumulative & o & 30” & $27^{\circ} \mathrm{C}$ & 8.5 & 2.5 & 11 & 0.08 & 86.2 \\
\hline $\mathbf{m m}$ & Retained/g & weight/g & $\%$ & 1' & $27^{\circ} \mathrm{C}$ & 8 & 2.5 & 10.5 & 0.055 & 84.2 \\
\hline 8 & 0 & 0 & 100 & 2 ' & $27^{\circ} \mathrm{C}$ & 7.5 & 2.5 & 10 & 0.038 & 80.2 \\
\hline 5 & 0 & 0 & 100 & 5, & $27^{\circ} \mathrm{C}$ & 7 & 2.5 & 9.5 & 0.025 & 76.2 \\
\hline 2 & 1 & 0.2 & 99.8 & 10 & $27^{\circ} \mathrm{C}$ & 5.5 & 2.5 & 8 & 0.017 & 64.2 \\
\hline 1.25 & 4 & 0.8 & 99.2 & 20 ' & $27^{\circ} \mathrm{C}$ & 4.5 & 2.5 & 7 & 0.012 & 56.2 \\
\hline 0.4 & 10 & 2 & 98 & $40^{\prime}$ & $27^{\circ} \mathrm{C}$ & 4 & 2.5 & 6.5 & 0.009 & 52.2 \\
\hline 0.32 & 22 & 4.4 & 95.6 & $1 \mathrm{~h} 20^{\prime}$ & $27^{\circ} \mathrm{C}$ & 3.5 & 2.5 & 6 & 0.006 & 48.2 \\
\hline 0.15 & 29 & 5.8 & 94.2 & $2 \mathrm{~h} 00$ & $27^{\circ} \mathrm{C}$ & 2 & 2.5 & 4.5 & 0.005 & 36.2 \\
\hline 0.08 & 59 & 11.8 & 86.2 & $24 \mathrm{~h} 00^{\prime}$ & $27^{\circ} \mathrm{C}$ & 1 & 2.5 & 3.5 & 0.001 & 28.2 \\
\hline
\end{tabular}


Table 5. Results of Atterberg Limits of Well $1 B$.

\begin{tabular}{lllllll}
\hline Specimens & A & B & C & D & E & F \\
\hline Number of blows & 17 & 22 & 27 & 32 & 32 & 32 \\
Quantity water (W/\%) & 82 & 81.38 & 80.84 & 80.4 & 28.1 & 28 \\
Average plasticity limit $\left(\mathrm{L}_{\mathrm{L}} / \%\right)$ & & & 28.05 & Average liquid limit & 81.02 & 52.97 \\
Plasticity Index $\left(\mathrm{P}_{\mathrm{I}} / \%\right)$ & & & & & \\
\hline
\end{tabular}

Table 6. Results of Atterberg Limits of Well $2 B$.

\begin{tabular}{lllllll}
\hline Specimens & G & H & I & J & K & L \\
\hline Number of blows & 17 & 22 & 27 & 32 & 32 & 32 \\
Quantity water (W/\%) & 85.04 & 84.38 & 83.78 & 83.30 & 26.13 & 26 \\
Average plasticity limit $\left(\mathrm{L}_{\mathrm{L}} / \%\right)$ & & & 26.05 & Average liquid limit & & 84 \\
Plasticity Index ( $\left.\mathrm{P}_{\mathrm{I}} / \%\right)$ & & & & & 57.94 \\
\hline
\end{tabular}

Table 7. Results of Atterberg Limits of Well $3 B$.

\begin{tabular}{lllllll}
\hline Specimens & M & N & O & P & Q & R \\
\hline Number of blows & 17 & 22 & 27 & 32 & 32 & 32 \\
Quantity water (W/\%) & 96.04 & 95.5 & 95 & 94.54 & Average liquid limit & 32 \\
Average plasticity limit $\left(\mathrm{L}_{\mathrm{L}} / \%\right)$ & & & 32 & & & \\
Plasticity Index $\left(\mathrm{P}_{\mathrm{I}} / \%\right)$ & & & & & 63.08 \\
\hline
\end{tabular}

Table 8. Summary of organic matter content and specific gravity.

\begin{tabular}{lllll}
\hline & & Well 1B & Well 2B & Well 3B \\
\hline & Initial weight (P1) & 80 & 80 & 80 \\
Organic matter content (OMC) & Dry weight (P2) & 77.85 & 78.8 & 78.45 \\
& P3=P2-P1 & 2.15 & 1.2 & 1.55 \\
& OMC (\%) & 2.69 & 1.5 & 1.94 \\
\hline
\end{tabular}

Table 9. Taylor Classification of Well 1 Well 2 and Well 3 Materials.

\begin{tabular}{lllll}
\hline & & Well 1B & Well 2B & Well 3B \\
\hline \multirow{3}{*}{ Percentage in materials } & \% clayey $(<2 \mu \mathrm{m})$ & 26.1 & 19.6 & 28.2 \\
& \% silty $(2 \mu \mathrm{m}<\mathrm{D}<50 \mu \mathrm{m})$ & 48.6 & 28.3 & 52 \\
& \% sandy $(50 \mu \mathrm{m}<\mathrm{D}<2 \mathrm{~mm})$ & 24.3 & 42.3 & 19.6 \\
\multirow{2}{*}{ Percentage relative to $\mathrm{D}<2 \mathrm{~mm}$} & \% clayey $(<2 \mu \mathrm{m})$ & 26.4 & 31.7 & 28.3 \\
& \% silty $(2 \mu \mathrm{m}<\mathrm{D}<50 \mu \mathrm{m})$ & 49.1 & 46.9 & 52.1 \\
Class & \% sandy $(50 \mu \mathrm{m}<\mathrm{D}<2 \mathrm{~mm})$ & 24.5 & Silty clayey sandy & 19.6 \\
\hline
\end{tabular}

\subsubsection{Classification in Accordance with Taylor}

The results are shown in Table 9. The Taylor classification (Table 9) leads to the conclusion that the soil is of At-Class: very plastic inorganic clay. Moreover, the classification NFP 11-300 or GTR 92 leads to the conclusion that it is a class A4 soil, that is to say, a silty clayey sandy, or madly clay is very plastic. Therefore, on both sections there is the presence of swelling soil. For this reason, in following section, this research will be focused on the improvement silty clayey sandy using cement in order to improve its bearing capacity.

\subsubsection{Improvement Silty Clayey Sandy with Cement}

To remedy the deterioration of infrastructure on the clayey soil, the methods such as mechanical, chemical stabilization, of the soil have been used to restore the deterioration of the soil [26-28]. The main objective of the soil stabilization is to increase the bearing capacity of the soil, its resistance to weathering process and soil permeability. The long-term performance of any construction project depends on the soundness of the underlying soils. Unstable soils can create

significant problems for pavements or structures.
Therefore, soil stabilization techniques are necessary to ensure the good stability of soil so that it can successfully sustain the load of the superstructure especially in case of soil which are highly active, also it saves a lot of time and millions of money when compared to the method of cutting out and replacing the unstable soil. For this reason, in this section of study, the cement is used to improve the clay soil.

The cement hydrate treatment has brought a substantial improvement at the California bearing ratio (CBR) of soil samples from the various sites as shown in Table 6. As shown in Table 6, the physical property tests of the improved soil sample have better properties compared to the physical property test of natural samples. The 3\% cement dosage of the soil sample used for the California bearing ratio (CBR) after immersion of $4 \mathrm{~d}$ over the California bearing ratio (CBR) value of soil sample not immersed is 293, verifying the criterion. This criterion states that the CBR at $95 \%$ of the treated silty sandy by cement must show a minimum value of $200 \%$ for the subbase layer. Basing on this criterion, although the CBR at $95 \%$ of the treated clay soil by $2 \%$ and $2.5 \%$ cement shows a minimum value of $200 \%$, these percentages cannot be used because, the same criterion states that, from $1 \%$ to $2.5 \%$ the minimum value must be, between $80 \%$ and $120 \%$. 
In past studies, some researchers showed that after 28 days of curing, a slight additional improvement in the soil was achieved. Although the compressive strength of the studied cemented soil was measured only after 7 days in these studies, it is believed that a considerable increase in this value was gained after 28 days of curing. According to Shrestha [29], the compressive strength of a soil mixed by cement after 28 days of curing can be nearly twice the compressive strength after 7 days. This, seems to be confirmed by this study. Shrestha [29] reported also that when using ordinary Portland cement as binder for stabilizing soil, the reaction between the binder and the soil almost finishes within the first month and the final strength is gained. For this reason, in this study, the evaluation of performance of cement on silty clayey sandy is done on period of 28 days. Hence, the achieved increase in compressive strength and tension strength in this study believed to be nearly final. In this study, the increase of percentage of cement, increases compressive strength and tension strength after 28 days. The treatment of silty clayey sandy with cement has led to great improvement in their characteristics (Table 10). The analysis of these different results made it possible to envisage a thorough study with $3 \%$ of cement on the sample, as presented in Table 10. But this percentage does not guarantee the stability of pavement, because, some of the previous studies which have focused on the use of lime, fly ash, cement, to improve the geotechnical properties of swelling clayey soils, stated that the application of chemical materials has been limited in unstable area as river area [30]. For this reason, in following section, this research will be focused on geogrid-reinforced soil.

Table 10. Properties of sample of soil according to compressive and tension strength tests.

\begin{tabular}{|c|c|c|c|c|c|c|c|c|c|c|c|c|c|}
\hline \multirow{2}{*}{ Parameter } & \multicolumn{2}{|l|}{ Proctor } & \multicolumn{3}{|c|}{$\begin{array}{l}\mathrm{CBR} / \% \text { at } 3 \mathrm{~d} \text { air, } 4 \mathrm{~d} \\
\text { water }\end{array}$} & \multicolumn{3}{|c|}{ Compressive strength/MPa } & \multicolumn{3}{|c|}{ Tension strength/MPa } & \multirow{2}{*}{$\begin{array}{l}C^{\prime} / \\
\text { C }\end{array}$} & \multirow{2}{*}{$\begin{array}{l}\mathrm{T}=100 \times \mathrm{C} \\
{ }^{\prime} / \mathrm{C}\end{array}$} \\
\hline & $\rho_{\max } /\left(\mathrm{t} . \mathrm{m}^{-3}\right)$ & $\mathrm{W} / \%$ & $\begin{array}{l}90 / \% \\
\text { OPM }\end{array}$ & $\begin{array}{l}95 / \% \\
\text { OPM }\end{array}$ & $\begin{array}{l}100 / \% \\
\text { OРМ }\end{array}$ & $\begin{array}{l}7 \text { d air } \\
\text { (C) }\end{array}$ & $\begin{array}{l}3 \text { d air, } 4 \text { d } \\
\text { water }\left(C^{\prime}\right)\end{array}$ & $\begin{array}{l}28 \mathrm{~d} \\
\text { air }\end{array}$ & $\begin{array}{l}7 \text { d air } \\
\text { (C) }\end{array}$ & $\begin{array}{l}28 \mathrm{~d} \\
\text { air }\end{array}$ & $\begin{array}{l}21 \text { d air, } 7 \text { d } \\
\text { water }\left(C^{\prime}\right)\end{array}$ & & \\
\hline $0 \%$ Cement & 1.98 & 8.4 & 22 & 40 & 60 & --- & 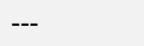 & --- & --- & --- & --- & -- & --- \\
\hline $2 \%$ Cement & 2 & 8.5 & 141 & 238 & 301 & 0.9 & 0.5 & 1.7 & 0.1 & 0.2 & 0.9 & 0.56 & 56 \\
\hline $2.5 \%$ Cement & 2.01 & 8.5 & 145 & 215 & 360 & 1.1 & 0.8 & --- & 0.1 & --- & -- & 0.73 & 73 \\
\hline $3.5 \%$ Cement & 2.04 & 8.2 & 274 & 371 & 453 & 1.9 & 1.44 & --- & 0.2 & -- & --- & 0.8 & 80 \\
\hline $4 \%$ Cement & 2.05 & 7.6 & 281 & 508 & 791 & 2.4 & 1.4 & 3.7 & 0.2 & 0.4 & --- & 0.6 & 60 \\
\hline $4.5 \%$ Cement & 2.05 & 8.2 & 317 & 567 & 692 & 2.9 & 1.4 & --- & 0.3 & --- & --- & 0.5 & 50 \\
\hline $5 \%$ Cement & 2.06 & 8 & 274 & 567 & 778 & 3.5 & 2.3 & 5.9 & 0.4 & 0.7 & --- & 0.66 & 66 \\
\hline $5.5 \%$ Cement & 2.06 & 8 & 391 & 700 & 840 & 3.7 & 2.52 & --- & 0.5 & --- & --- & 0.7 & 70 \\
\hline
\end{tabular}

\subsection{Numerical Modeling of Pavement with and Without Reinforcement by Geogrid}

Past studies have shown that geogrid reinforced soil processing has been used in basic engineering. In general, the presence of flexible polymer reinforcement creates a quite complicated three phases of soil structure composed, reinforcement and soil-reinforcement structure. Onto this principle, geosynthetics architecture must be designed to maximize geogrid benefits and thus save cost. Definitely, Current literature has focused on mathematical experiments and numerical simulations to establish a cost effective and efficient methodology to geosynthetic reinforcement to improve bearing strength and stabilization for shallow foundations [31-35].

Geogrid-reinforced soil structures as a flexible alternative to conventional construction methods, e.g., concrete retaining walls, also allow for the preparation of land for building even under difficult topographic conditions [3034]. Geogrid-reinforced steep slopes enable the development of land for building on a limited space, which is extremely beneficial in the case of expensive land prices. From an economical viewpoint, a reduction in the overall construction costs of at least $30 \%$ can be achieved compared to conventional methods [31-35]. The use of FEM in determining the stress, strains and deflections are becoming widely popular thanks to its ability to handle structures with nonlinear materials. However, in a lot of these simulations, the traffic loading is generally considered as static one [36]. The incorporation of traffic loading as a dynamic loading is still in its stage research [36]. Figures 7 and 8 show the undeformed and deformed shape of the geogrid on an exaggerated scale.

From Figures 7 and 8, the deformation of geogrid in subgrade is less than the deformation of geogrid in crushed stones base layer and interface of crushed stones basesubbase layers. Therefore, the variation of deformation geogrid depends on the position of geogrid in the pavement layer.

"Rutting" is defined as the permanent deformation of a pavement due to the progressive accumulation of viscoplastic vertical compressive strains under traffic loading. On the pavement surface, it manifests as longitudinal depressions in the wheel tracks. Significant rutting can lead to major structural failures and hydroplaning potentials [36].

Hugo et al (1999) related rutting to pavement functional performance, and defined rutting as the vertical gap left under an imaginary straightedge, $1.2 \mathrm{~m}$ long straddled across the wheel path with both ends on the pavement [37]. 


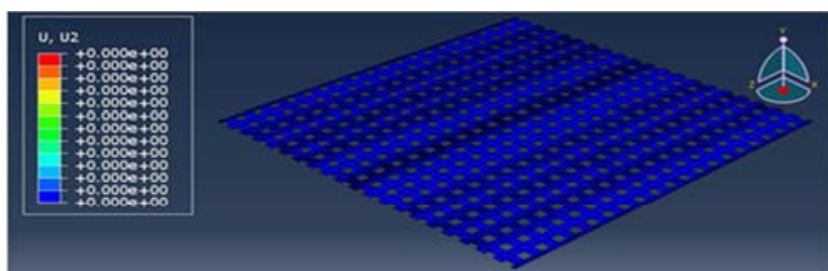

a-Undeformed geogrid for pavement from kilometric point $15+750$ to $15+850$

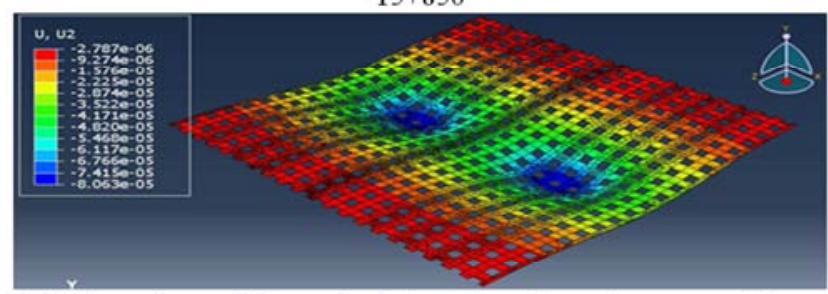

b-Deformed geogrid in crushed stones base layer for pavement from kilometric point $15+750$ to $15+850$

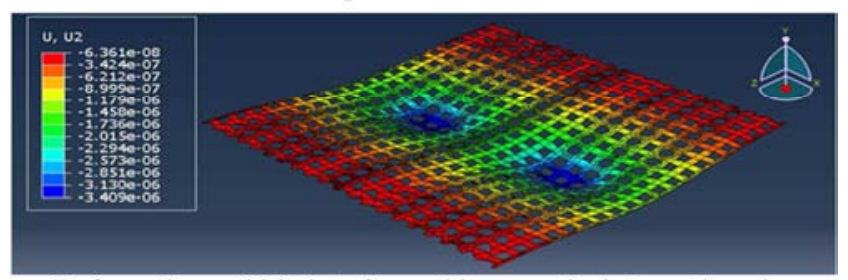

c-Deformed geogrid in interface subbase-crushed stones base layer for pavement from kilometric point $15+750$ to $15+850$

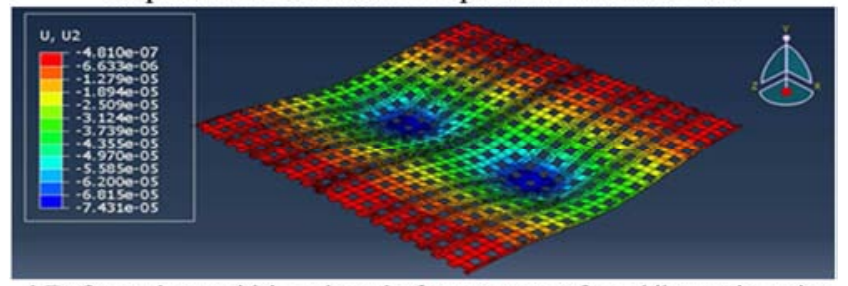

d-Deformed geogrid in subgrade for pavement from kilometric point $15+750$ to $15+850$

Figure 7. Undeformed and deformed shape of the geogrid for pavement from kilometric point $15+750$ to $15+850$.

One of past studies stated that, surface ruts may occur in the asphalt-surfacing layer under the action of heavy vehicle loading, particularly in areas of extreme high temperatures. Principally, the surface rutting in the asphalt layer is mainly caused by shear deformation [37] coupled with highlocalized vertical compressive stresses in the top zone. Asphalt-mix densification due to traffic loading is another contributing factor. Pavement uplift (shoving) may also occur along the sides of the rut [36].

The response of a pavement structure to traffic loading is mechanistically modelled by computing stresses and strains within its layers. If excessive, stresses may cause pavement fatigue cracking and/or surface rutting. This may result in both structural and functional failure, thus causing a safety hazard to motorists [35]. Pavement stress-strain analysis is an ideal tool for analytical modelling of pavement behaviour and thus, constitutes an integral part of pavement design and performance evaluation. It is the fundamental basis for the mechanistic design theory [36].

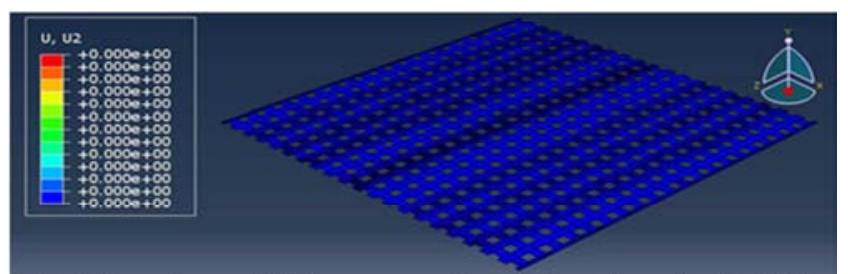

a-Undeformed geogrid for pavement from kilometric point $16+100$ to $16+200$

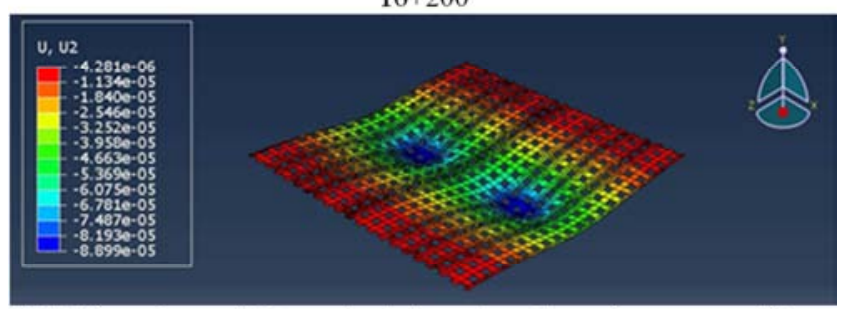

b-Deformed geogrid in crushed stones base layer for pavement from kilometric point $16+100$ to $16+200$

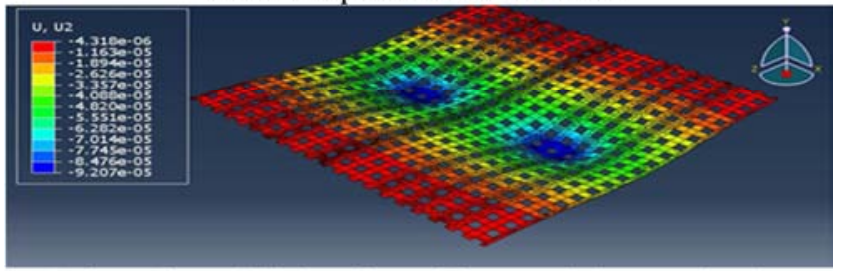

c-Deformed geogrid in interface subbase-crushed stones base layer for pavement from kilometric point $16+100$ to $16+200$

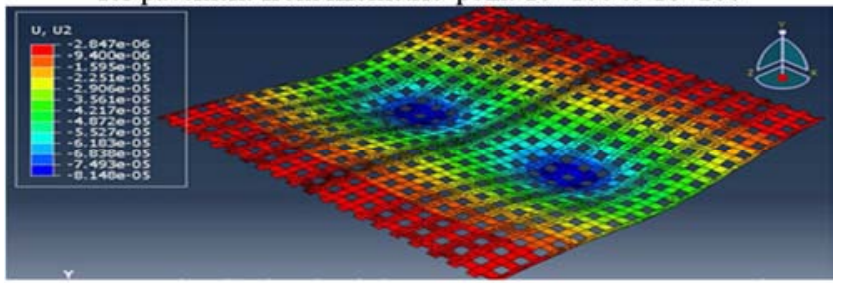

d-Deformed geogrid in subgrade for pavement from kilometric point $16+100$ to $16+200$

Figure 8. Undeformed and deformed shape of the geogrid for pavement from kilometric point $16+100$ to $16+200$.

With the ever-increasing truck tyre loading and inflation pressures, a better understanding of the pavement stressstrain behaviour is an enhancement in the development of more constitutive design models centred on pavement-traffic load response and distress minimization. The wide use of thin asphalt surfacing's $(\leq 50 \mathrm{~mm})$ in Southern Africa which are considered economical, entails that more studies are needed into understanding the traffic load response of these layers $[36,39]$.

The deflection, stress and strain comparisons are shown in Figures 9 and 10.

From the deflection, stress and strain comparisons which are shown in Figures 9 and 10; it can be seen that lowest values strain and stress are found at the pavement with subgrade reinforced by geogrid and maximum strain occurs when the geogrid is in interface crushed stones base layer material just under the wheel load application point.

Also, it can be noted that the pavement reinforced by geogrid in crushed stones base-improved cement subbase interface has greater values for stress and strain than all other possible pavement reinforced by geogrid at other position in 
the pavement layer. In both cases of pavement board, the figure shows that the longitudinal strain increases according to the variation of geogrid position from the improved cement subbase to the crushed stones base layers. With the interface of crushed stones base- improved cement subbase layers reinforced by geogrid; it noticed the increments longitudinal strain compared to others positions. In the case of pavement board with geogrid in subgrade, the longitudinal strain is lower than the longitudinal strain of pavement reinforced by geogrid from the improved cement subbase to the crushed stones base layers.
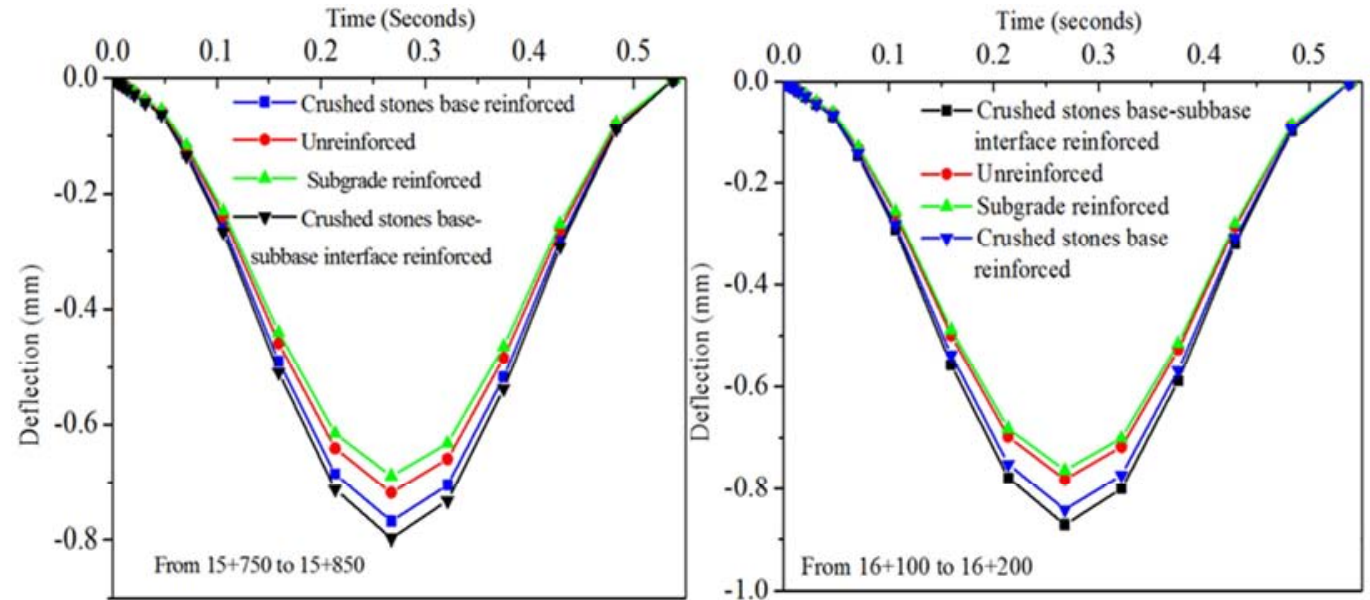

Figure 9. Comparison of time-deflection histories between pavements of non-reinforced and reinforced at different position layers from kilometric point $15+750$ to $15+850$ and from $16+100$ to $16+200$
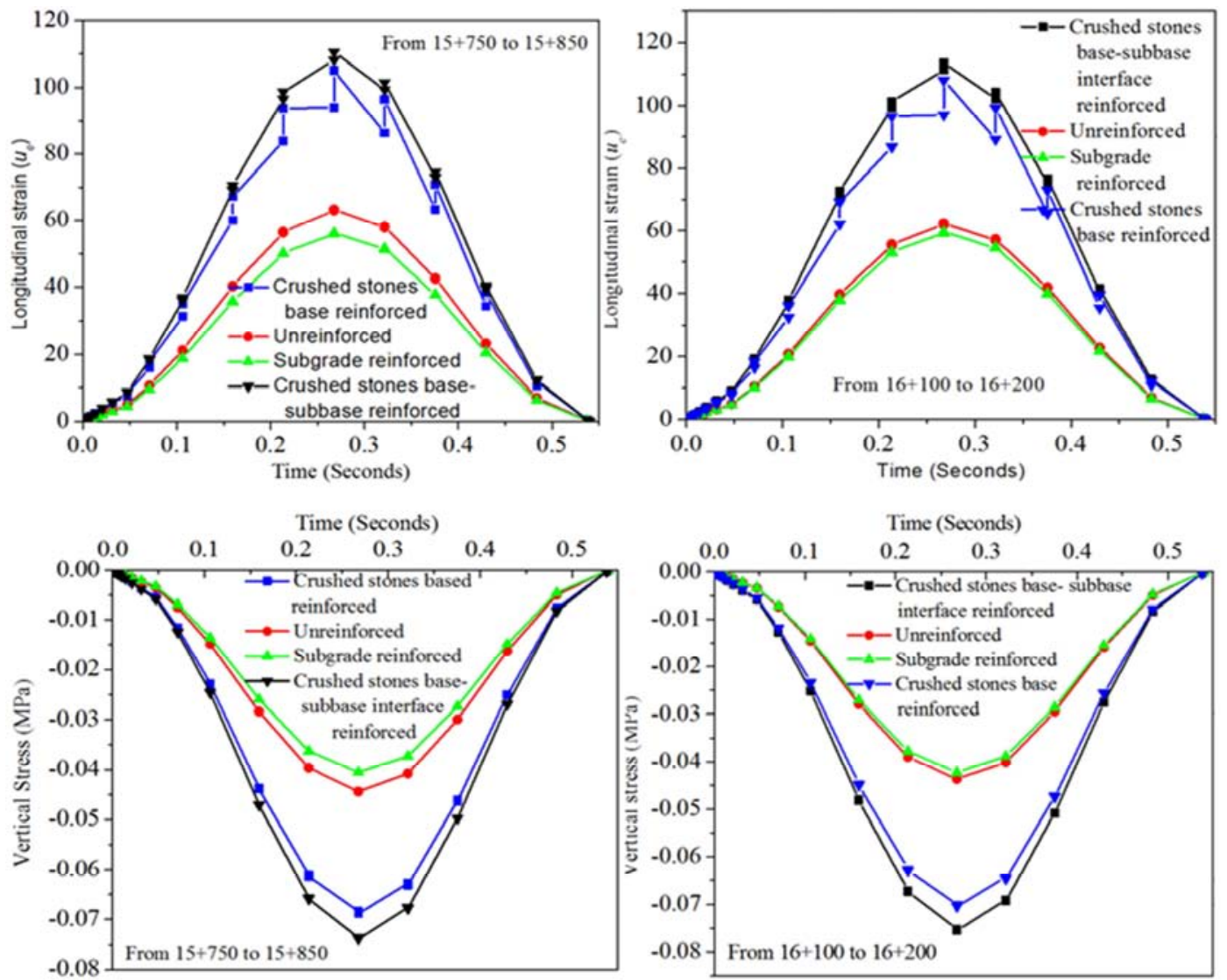

Figure 10. Comparison of (a) longitudinal strain for pavement non-reinforced and reinforced at different position layers and on (b) vertical stress for pavement no reinforced and reinforced at different position layers (all for rectangle loading areas) from kilometric point $15+750$ to $15+850$ and from 16+100 to $16+200$.

Vertical stress variations are shown in Figure 10. Vertical stress increases for pavement from kilometric point $16+100$ to $16+200$ and from $15+750$ to $15+850$, with different position of geogrid in pavement layer. For geogrid in 
interface improved cement subbase-crushed stones base layer, vertical stress is maximum. Vertical stress is minimum for geogrid in the subgrade. A similar trend is observed in both cases of pavement. As noted earlier, vertical deflection increases according to the variation of geogrid position from the improved cement subbase to the crushed stones base layers for the same amount of vertical load. An increase in vertical deflection causes an increase in longitudinal strain (Figures 9 and 10). Therefore, vertical stress increases with longitudinal strain.

Regarding the low values longitudinal strain and vertical stress of pavement (Figure 10) when the geogrid is used in subgrade, this can be justified because of the vertical moisture barriers with geogrid could reduce the moisture variation in subgrade and restrain pavement roughness. This result is confirm by others researchers [40] whereas, the geogrid in crushed stones base- improved cement subbase layer interface and the geogrid in crushed stones base layer did not confirm the research which state that the geogrid serves as an initial barrier to upward crack propagation and the flexible layer overlay on the top of the geogrid serves as stress relief layer [41].

\section{Conclusions}

This paper is based on the enhancing performance of silty clayey sandy and of pavement using cement and geogrid in south Republic of Benin (West Africa). In this research, laboratory tests were performed on natural silty clayey sandy extracted from different locations in the south of Republic of Benin.

The first part of this study based on the Taylor classification; leads to the conclusion that the soil is very plastic inorganic clay. Moreover, the classification leads to the conclusion that it is a class A4 soil, that is to say, a silty clayey sandy, or madly clay is very plastic.

Then, the second part of the study was devoted toward investigating the ability to improve these soils using the mixing technology method by measuring their compressive strength after hardening of the soils when mixed with cement at different cement dosages. Considering the second objective of this paper, it has been discovered that in general, the values of the California bearing ratio (CBR) index of the clay soil are less than 80 . With the addition of cement, the California bearing ratio (CBR) index experienced a very appreciable improvement. The performances recorded after incorporation of $3 \%$ cement are above the recommended values for the materials destined for the subbase layers. Apart from the California bearing ratio (CBR) index, all other parameters have reached the thresholds generally recommended for improved subbase layer materials and California bearing ratio (CBR) of at least 200 is required in the laboratory for the subbase layer. The proportion leading to these performances varies from $3 \%$ to $5.5 \%$. Viewing all the above, the research recommends that the silty clayey sandy, treated with cement can be used for the subbase layers where the California bearing ratio $(\mathrm{CBR})$ index required is greater than or equal to 200. Besides, it is important to note that, the performance of the sub-base layer depends on the rate of silty clayey soil in the improved soil.

Finally, regarding the performance of pavement using silty clayey sandy treated with $3 \%$ cement in subbase and or not geogrid, this pavement without the geogrid in subgrade is technically better than the following: firstly, the type of pavement structure with geogrid placed at the interface of the crushed stones base layer and improved cement subbase layer, and secondly, the same pavement structure with geogrid in the crushed stones base layer. Since the mean deflections of these pavements with geogrid in crushed stones base layer and geogrid in interface crushed stones base- improved cement subbase layer, are approximately the double of the mean deflection of the pavement without geogrid. In this perspective, this research gives the optimal position of the geogrid in subgrade by showing us that the pavement made with geogrid in subgrade is the best in relation to the pavement without geogrid. For this reason, the future work will consist, an experimental test to verify the optimal position of geogrid in order to validate the finite element model.

\section{Acknowledgements}

We gratefully acknowledge financial support for this research from State Key Program of National Natural Science Foundation of China (Grant No. 41430634), the National Major Scientific Instruments Development Project of China (Grant No. 41627801), and the Technology Research and Development Plan Program of Heilongjiang Province (Grant No. GA19A501).

\section{References}

[1] Laubach S E, Olson J E, Gross M R. Mechanical and fracture stratigraphy [J]. AAPG bulletin, 2009, 93 (11): 1413-1426.

[2] Farifteh J, Farshad A, George R. Assessing salt-affected soils using remote sensing, solute modelling, and geophysics $[\mathrm{J}]$. Geoderma, 2006, 130 (3-4): 191-206.

[3] Loveland P. Soil Genesis and Classification [M]// Soil genesis and classification /. 1980.

[4] Nicholson G A, Bieniawski Z T. A nonlinear deformation modulus based on rock mass classification $[\mathrm{J}]$. International Journal of Mining \& Geological Engineering, 1990, 8 (3): $181-202$.

[5] Al-Rawas A A, Mcgown A. Microstructure of Omani expansive soils [J]. Canadian Geotechnical Journal, 1999, 36 (2): $272-290$

[6] Amšiejus J, Dirgèlienè N, Norkus A. Comparison of sandy soil shear strength parameters obtained by various construction direct shear apparatuses [J]. Archives of Civil and Mechanical Engineering, 2014, 14 (2): 327-334.

[7] Tangchaosheng, Shibin, Cuiyujun, et al. Desiccation cracking behavior of polypropylene fiber-reinforced clayey soil [J]. Canadian Geotechnical Journal, 2012, 49 (9): 1088-1101. 
[8] Hardy F. Studies in tropical soils. III. The shrinkage behaviour of lateritic and kaolinitic soils [J]. Journal of Agricultural Science, 1934, 24 (1): 59-71.

[9] Ghasabkolaei N, Choobbasti A J, Roshan N. Geotechnical properties of the soils modified with nanomaterials: A comprehensive review [J]. Archives of Civil and Mechanical Engineering, 2017, 17 (3): 639-650.

[10] Kazmierczak J-B, Maison T, Laouafa F. Un nouveau dispositif pour la caractérisation du retrait et du gonflement des sols argileux [J]. Revue Française de Géotechnique, 2016 (147): 1.

[11] Mouroux P, Margron P, Pinte J-C. La construction économique sur sols gonflants [M]. Editions BRGM, 1988, 14

[12] Snethen D R. Characterization of expansive soils using soil suction data [C]//ASCE, 1980: 54-75.

[13] Tsiambaos G, Tsaligopoulos C. A proposed method of estimating the swelling characteristics of soils: Some examples from Greece [J]. Bulletin of the International Association of Engineering Geology - Bulletin de l'Association Internationale de Géologie de l'Ingénieur, 1995, 52 (1): 109-115.

[14] Attoh-Okine N. Lime treatment of laterite soils and gravels-revisited $[\mathrm{J}]$. Construction and Building Materials, 1995, 9 (5): 283-287 (in France).

[15] Wathugala G, Huang B, Pal S. Numerical simulation of geosynthetic-reinforced flexible pavements [J]. Transportation Research Record: Journal of the Transportation Research Board, 1996 (1534): 58-65.

[16] Saad B, Mitri H, Poorooshasb H. Three-dimensional dynamic analysis of flexible conventional pavement foundation [J]. Journal of transportation engineering, 2005, 131 (6): 460-469.

[17] Afnor N. 94-056. Analyse granulométrique: méthode par tamisage à sec après lavage $[\mathrm{M}]$. Normalisation Française, 1992.

[18] Afnor N. 94-056. Analyse granulométrique: Méthode par tamisage [M]. Normalisation Française, 1996.

[19] Afnor. NF P94-051. Reconnaissance et essai de détermination des limites d'Atterberg [M]. Normalisation Française, 1993: 15 .

[20] Afnor. NF P94-093- Détermination des caractéristiques de compactage d'un sol, essai Proctor normale, essai Proctor modifié [M]. Normalisation Française, 1993: 14.

[21] Astm D3282-09. Standard Practice for Classification of Soils and Soil-Aggregate Mixtures for Highway Construction Purposes [M]. ASTM International, West Conshohocken, PA, www.astm.org., 2009.

[22] Afnor. EN 13286-2-Mélanges traités et mélanges non traités aux liants hydrauliques Partie 2 : méthodes d'essai de détermination en laboratoire de la masse volumique de référence et de la teneur en eau - Compactage Proctor [M]. Normalisation Française, 2010.

[23] Afnor. EN 13286-50. Unbound and hydraulically bound mixtures - Part 50: Method for the manufacture of test specimens of hydraulically bound mixtures using Proctor equipment or vibrating table compaction [M]. Normalisation Française, 2004.

[24] Zaghloul S M, White T. Use of a three-dimensional, dynamic finite element program for analysis of flexible pavement $[\mathrm{J}]$. Transportation research record, 1993 (1388).

[25] Park S, Kim Y. Fitting Prony-series viscoelastic models with power-law presmoothing [J]. Journal of Materials in Civil Engineering, 2001, 13 (1): 26-32.

[26] Harris P. Evaluation of stabilization of sulfate soils in Texas [R]. Texas Transportation Institute, Texas A \& M University System, 2008.

[27] Sebesta S. Investigation of maintenance base repairs over expansive soils: Year 1 report [R]. Texas Transportation Institute, Texas A \& M University System, 2002.

[28] Dawie M, Jacobsz SW. Optimal placement of reinforcement in piggyback landfill liners [J]. Geotextiles \& Geomembranes, 2018, 46 (3): 327-337.

[29] Shrestha R. Soil Mixing: A Study on 'Brusselian Sand' Mixed with Slag Cement Binder [D]. PhD diss., Master Dissertation, University of Ghent, University of Brussle, 2008.

[30] Alaye QE, Ling XZ, Tankpinou YS, Ahlinhan MF, Luo J, Alaye $\mathrm{MH}$. Enhancing performance of soil using lime and precluding landslide in Benin (West Africa) [J]. Journal of Central South University. 2019, 26 (11): 3066-86.

[31] Huang C C, Tatsuoka F. Bearing capacity of reinforced horizontal sandy ground [J]. Geotextiles and Geomembranes, 1990, 9 (1): 51-82.

[32] Dash S K. Influence of relative density of soil on performance of geocell-reinforced sand foundations [J]. Journal of Materials in Civil Engineering, 2010, 22 (5): 533-538.

[33] Dash S K, Sireesh S, Sitharam T. Model studies on circular footing supported on geocell reinforced sand underlain by soft clay [J]. Geotextiles and Geomembranes, 2003, 21 (4): 197219.

[34] Sitharam T, Sireesh S, Dash S K. Model studies of a circular footing supported on geocell-reinforced clay [J]. Canadian Geotechnical Journal, 2005, 42 (2): 693-703.

[35] Wang J, Zhou J, Cong L. Analysis between numerical and field tests of high fill reinforced widening embankment $[\mathrm{J}]$. Chinese Journal of Rock Mechanics and Engineering, 2010, 29 (S1): 2943-2950.

[36] Walubita, L. F., \& Van de Ven, M. F. Stresses and strains in asphalt-surfacing pavements [c]// SATC 2000.

[37] Hugo F, Fults K, Chen Dar-Hao, Smit ADF, and Bilyeu J, 1999. An Overview of the TxMLS Program and Lessons Learned (GS3-4) [C]// Paper presented at the International Conference on Accelerated Pavement Testing in Reno, Nevada. October 1999.

[38] Park DW, Martin AE, Masad E. Effects of nonuniform tire contact stresses on pavement response [J]. Journal of Transportation Engineering, 2005, 131 (11): 873-879.

[39] De Beer M, Kanneier L, and Fisher C. Towards Improved Mechanistic Design of Thin Asphalt Layer Surfacings based on actual Tyre/Pavement Conatact Stress-In-Motion (SIM) Data in South Africa [C]// In Proceedings 1999.

[40] Jayatilaka R, Lytton R L. Prediction of expansive clay roughness in pavements with vertical moisture barriers [R]. No. FHWA/TX-98/187-28F, 1997. 
[41] Dessouky S H, OH J, Ilias M. Investigation of various pavement repairs in low-volume roads over expansive soil [J]. Journal of Performance of Constructed Facilities, 2014, 29 (6): 04014146. 